K A N D A I

\begin{tabular}{|l|l|l|}
\hline Volume 15 & No. 2, November 2019 & Halaman 237-248 \\
\hline
\end{tabular}

\title{
KONSEPTUALISASI PANCASILA \\ DALAM METAFORA BAHASA INDONESIA: SEBUAH KAJIAN AWAL (Conseptualization of Pancasila in Indonesian Metaphor: An Early Study)
}

\author{
Bakdal Ginanjar \& Chattri S. Widyastuti \\ Universitas Sebelas Maret \\ Jalan Ir. Sutami 36A, Surakarta 57126, Indonesia \\ Pos-el: bakdalginanjar@staff.uns.ac.id
}

(Diterima 1 April 2019; Direvisi 28 September 2019; Disetujui 30 September 2019)

\begin{abstract}
Pancasila is an Indonesian ideology and becomes the basis, outlook on life and philosophy in social life. However, understanding and appreciation of Pancasila is considered to have begun to decline in various lives. Based on that reality, this study examines the recent Pancasila conceptualization mapping in print mass media with a conceptual metaphor perspective. This research is a qualitative descriptive type in linguistics that seeks to see people use real language in a discourse to find out the conceptualization of abstract ideas and emotions. From articles on Pancasila in the printed mass media that were collected by listening methods and note techniques, metaphors about Pancasila were identified and analyzed with conceptual metaphor theory through the referential equivalent method. The results of the analysis showed a correspondence between the source and target domains. Pancasila is conceptualized with something else based on the functions, strengths, characteristics, traits, and human experience. Based on the conceptual metaphorical perspective, Pancasila is mapped on "Pancasila Is House", "Pancasila Is Empty Container", "Pancasila Is Fortress", "Pancasila Is Clothing", and "Pancasila Is Evenence".
\end{abstract}

Keywords:conceptual metaphor, Pancasila, source, target

\begin{abstract}
Abstrak
Pancasila merupakan ideologi Indonesia dan menjadi dasar, pandangan hidup, dan falsafah dalam kehidupan bermasyarakat. Namun, pemahaman dan penghayatan pada Pancasila dinilai sudah mulai menurun dalam berbagai kehidupan.Berdasarkan realita itu, penelitian ini mengkaji pemetaan konseptualisasi Pancasila akhir-akhir ini dalam media massa cetak dengan perspektif metafora konseptual. Penelitian ini berjenis deskriptif kualitatif dalam linguistik yang berusaha melihat masyarakat menggunakan bahasa secara nyata dalam sebuah wacana untuk mengetahui konseptualisasi dari ide dan emosi yang abstrak. Dari artikel tentang Pancasila dalam media massa cetak yang dikumpulkan dengan metode simak dan teknik catat, metafora tentang Pancasila diidentifikasi dan dianalisis dengan teori metafora konseptual melalui metode padan referensial .Hasil analisis menunjukkan adanya korespondensi antara ranah sumber dengan ranah target. Pancasila dikonseptualkan dengan sesuatu yang lain berdasarkan fungsi, kekuatan, ciri, sifat, dan pengalaman manusia. Berdasarkan perspektif metafora konseptual, Pancasila dipetakan atas "Pancasila Adalah Rumah", "Pancasila Adalah Wadah Kosong", "Pancasila Adalah Benteng", "Pancasila Adalah Pakaian", dan "Pancasila Adalah Keabadian”.
\end{abstract}

Kata-kata kunci: metafora konseptual, Pancasila, sumber, target

DOI: $10.26499 / j k . v 15 i 1.940$

How to cite: Ginanjar, B. \& Widyastuti, C.S. (2019). Konseptualisasi pancasila dalam metafora bahasa Indonesia: sebuah kajian awal. Kandai, 15(2), 237-248 (DOI: 10.26499/jk.v15i1.940) 


\section{PENDAHULUAN}

$\begin{array}{ccr}\text { Beragam } & \text { metode } & \text { maupun } \\ \text { pendekatan } & \text { diperlukan } & \text { untuk }\end{array}$ merumuskan representasi masyarakat terhadap ideologi sebuah negara. Penyelidikan secara mendalam terhadap permasalahan tersebut menjadi urgen tatkala timbul bibit-bibit yang mencoba maupun melakukan kegiatan untuk menggeser ideologi negara dan memudarnya pemahaman serta pengamalan atas ideologi negara.Akhirakhir ini, kenyataan tersebut mulai marak terjadi di Indonesia. Dalam hasil survei tahun 2017 yang dilakukan Kompas, tergambar dari 100 orang Indonesia, terdapat 27 orang yang tidak hafal sila-sila Pancasila (kompas.com, 2017). Hasil ini mengindikasikan menurunnya kebermaknaan Pancasila di mata masyarakat Indonesia saat ini yang berhubungan erat dengan banyaknya kejadian yang bersumber dari radikalisme, terorisme, liberalisme, dan kapitalisme.

Berangkat dari fenomena tersebut, penelitian ini mengkaji pemetaan konseptualisasi Pancasila sebagai sebuah ideologi dengan perspektif metafora kognitif. Perspektif metafora dalam ilmu linguistik ini merumuskan cara masyarakat menggunakan bahasa secara nyata, baik lisan maupun tulisan, untuk memahamkan konseptualisasi atas berbagai ide dan emosi yang abstrak yang terdapat dalam pikiran (Kovecses, 2005). Dari perspektif tersebut, diketahui penstrukturkan ide sebagai sebuah konsep dan bagaimana pengomunikasiannya melalui bahasa.

Sementara itu, ideologi menghubungkan pengalaman manusia yang realistis terhadap konsep filosofis tertentu yang abstrak. Konsep tersebut sebagian besar tidak memungkinkan untuk diungkapkan secara langsung karena keterbatasan kosakata dalam sebuah bahasa dalam pengungkapan hubungan antara sesuatu yang realistis dan abstrak.Untuk itu, metafora dapat menjadi jembatan menstrukturkan konsep tersebut menjadi sesuatu yang konkret (Rajandran, 2017).

Penelitian tentang representasi Pancasila melalui perspektif metafora ini belum pernah dilakukan sebelumnya.N amun, penelitian metafora konseptual mulai merebak di Indonesia dengan berbagai topik. Pasaribu (2013) meneliti metaforacinta dalam bahasa Indonesia, dan menemukan sekurang-kurangnya sembilan konseptualisasi metafora. Dengan sembilan konseptualisasi itu, cinta disamakan dengan makanan, sesuatu yang indah, suhu, cahaya, kegilaan, tenaga, pelajaran, dan perjalanan. Prayogi (2013) dengan kerangka teori yang sama melihat bagaimana penutur bahasa Indonesia mengonseptualisasi waktu. Dalam penelitiannya, ditemukan kognisi manusia untuk membayangkan waktu sebagai uang, perjalanan, tali, benda, roda, makanan, mahluk hidup, sesuatu yang berjarak, dan sesuatu yang memiliki dimensi. Sementara itu, Wijana (2015) mengulas bagaimana konseptualisasi korupsi di Indonesia dalam bingkai metafora. Penelitian tersebut menyimpulkan bahwa korupsi dipersepsikan dalam tujuh buah konsep: hama atau penyakit, musuh, sesuatu yangharus dipelajari, rintangan, benda, peristiwa, dan tindakan. Di sisi lain, Hartanto (2018) mengkaji metafora yang timbul dari penceramah agama Islam di Kota Surakarta. Hasil penelitian menunjukkan adanya hubungan antara tingkat kemetaforisan, ranah sumber dan target, dan ekpresivitas metafora. Penceramah menggunakan percampuran pengalaman lama dan baru pada leksion mental dalam bertutur secara metafora. Tuturan metafora tersebut disesuaikan dengan latar belakang peserta pengajian 
yang dihadapi. Demikian halnya, Subhan, et al. (2019) mendeskripsikan konseptualisasi sifat dan perbuatan yang terbentuk dari metafora dalam Alquran. Dalam simpulan penelitiannya, dinyatakan bahwa konseptualisasi sifat terbentuk berdasarkan data metafora dengan ranah sasaran antara lain: sifat kikir, sifat pengasih, sifat benci, dan sifat berlebihan. Sementara itu, konseptualisasi perbuatan terbentuk berdasarkan data metafora dengan ranah sasarannya antara lain: tindakan pemalsuan, tindakan maksiat, tindakan menyerang, tindakan menyentuh, dan tindakan pertanggungjawaban.

Masalah tentang Pancasila dipilih sebagai objek kajian dalam penelitian ini dengan harapan agar ditemukan berbagai pemahaman yang bersangkutan dengan persepsi masyarakat Indonesia secara umum terhadap Pancasila dalam sudut pandang metafora dan permasalahan yang timbul disekitarnya. Selanjutnya, dimungkinkan akan bermanfaat bagi usaha penanganan masalah lunturnya penghayatan Pancasila. Dalam hal ini, dapat diaplikasikan pada penataan pemetaan metafora untuk pengomunikasian Pancasila kepada masyarakat.

\section{LANDASAN TEORI}

Pada dasarnya, banyak ahli yang telah menyinggung mengenai metafora dalam berbagai referensi. Keraf (2004) menyatakan bahwa metafora termasuk dalam analogi yang membandingkan suatu hal dengan hal lainnya tanpa menggunakan kata-kata seperti, jikalau, dan sebagai. Tujuannya adalah agar hal pertama langsung merujuk pada hal kedua.

Parera (2004) mendeskripsikan metafora sebagai salah satu jalan pintas dalam pemberiaan nama untuk suatu lambang tertentu. Hal ini disebabkan tidak semua pengalaman baru dapat diberikan nama-nama baru atau simbol yang baru pula. Adanya keterbatasan manusia dalam penamaan disebabkan oleh penemuan pengalaman yang lain dan berbeda dengan pengalaman dasar pertama. Oleh karena itu, manusia mencari jalan pintas dalam pemberian nama yang selanjutnya diistilahkan sebagai metafora.

Ullman (2007) mengungkapkan bahwa struktur dasar metafora sangat sederhana karena terdiri atas dua. Dua hal tersebut dikatakan sebagai tenor atau sesuatu yang sedang dibicarakan dan wahana atau bandingan dari tenor tersebut. Persamaan merupakan relasi persamaan antara tenor dan wahana. Ullman (2007) menyatakan bahwa hubungan persamaan tersebut dapat berupa persamaan objektif, seperti bentuk, tempat, sifat, atau kombinasi di antaranya atau dapat pula berupa persamaan emotif.

Sejalan dengan Ullman, Subroto (2011) mengatakan bahwa metafora merupakan bentuk kreativitas penggunaan bahasa atau dapat dikatakan bahwa yang kreatif adalah penggunanya. Metafora pada dasarnya diciptakan atas persamaan antara dua satuan atau dua term. Persamaan tersebut tidak menyeluruh sifatnya, tetapi hanya dalam beberapa aspek saja. Persamaan tersebut dapat berupa wujud fisik, atau dalam hal sifat atau karakter, atau berdasarkan persepsi seseorang (persepsi diartikan sebagai daya tangkap, daya paham, daya merasakan).

Pandangan atas metafora tersebut terus berkembang secara dinamis sampai saat ini. Hal ini diawali oleh pendapat Lakoff dan Johnson (2003) bahwa metafora tidak hanya tampak pada katakata yang diciptakan, tetapi berada pada tiap konsep dari sebuah argumen. Metafora berada di dalam sistem konseptual dan cara berpikir manusia. 
Metafora ini dikenal selanjutnya dengan istilahmetafora konseptual. Metafora konseptual adalah sesuatu yang sistematis. Hal itu disebabkan oleh bahasa yang digunakan manusia juga sistematis, termasuk konsep yang terdapat di dalamnya. Jadi, metafora adalah hal yang sistematis dan struktural. Lakoff dan Johnson (2003) memberikan definisi yang mendasar bahwa metafora tidak berada pada tataran pemanis atau retoris dalam ungkapan kebahasaan ataupun sastra, tetapi sudah masuk dalam sistem konseptual manusia. Lebih lanjut, Lakoff dan Johnson menyatakan bahwa metafora adalah pemahaman serta pengalaman dari sesuatu yang dibandingkan dengan sesuatu yang lain.

Pandangan tersebut selanjutnya memengaruhi ahli-ahli lain, seperti Kovecses (2010) yang mendefinisikan metafora sebagai suatu bentuk pemahaman atas satu ranah konseptual dengan ranah konseptual yang lain. Dalam metafora konseptual, satu ranah dari pengalaman manusia digunakan untuk memahami ranah pengalaman yang lain. Demikian pula, Hurford, et al. (2007) menyatakan bahwa metafora merupakan konsep (mental) yang tecermin dalam bahasa manusia yang membuat penutur menata dan menafsirkan suatu pengetahuan abstrak dan pengalaman ke dalam istilah yang lebih konkret.

Dalam sistem konseptual tersebut, terjadi korespondensi yang sistematis antara sesuatu yang dinamakan ranahsumber (source domain) dengan ranahtarget (target domain) (Kövecses, 2010). Korespondensi konseptual ini disebut sebagai pemetaan.

Sumber merupakan konsep yang dijadikan dasar konseptualisasi dan target merupakankonsep dimana konseptualisasi itu diarahkan. Berdasarkan penjelasan Lakoff dan Johnson (2003) yang diperkuat oleh
Kovecses (2010), ranah sumber adalah ranah yang bersifat konkret atau fisik serta konsepnya lebih jelas dibandingkan ranah target yang cenderung abstrak. Pemilihan suatu sumber tertentu untuk suatu target dilakukan atas dasar pengalaman yang dirasakan tubuh ketika mengalami kondisi yang dirasakan.

$$
\text { Menurut Kovecses (2010), }
$$
kesamaan tidak selalu menjadi dasar untuk menunjukkan hubungan antara sumber dan target. Yang lebih menonjol adalah adanya konseptualisasi yang berkorespondensi antara sumber dan target. Lanjutnya, untuk memahami dua konsep (A dan B atau ranah sumber dan ranah target) dalam proses metaforis dibutuhkan satu kumpulan korespondensi yang sistematis antara keduanya. Dalam hal ini, unsur pokok elemen konsep B sesuai dengan unsur elemen pokok A. Secara teknis, korespondensi konseptual sering disebut sebagai (mapping/correspondence).

Pemetaan menjadi langkah utama dalam menghubungkan antara sumber dan target. Tujuannya adalah menghasilkan titik kesamaan konsep antara keduanya. Untuk menjalankannya, diperlukan konseptualisasi pengalaman (Nirmala, 2014). Pengalaman itu dimanfaatkan untuk melukiskan kejadian, perasaan, dan pikiran yang terdapat dalam kehidupan manusia. Secara teknis, hal itu dijalankan dengan strategi menghidupkan memori semantik yang berkaitan dengan pengalaman tubuh, ciri, fungsi, dan kekuatan yang dimiliki sumber untuk dibandingkan dengan target. Strategi ini dinamakan strategi asosiatif (Nirmala, 2014).

Pemetaan konseptual dari korespondesi tersebut ditampilkan dalam bentuk ' $X$ is $Y$ ' (' $\mathrm{X}$ adalah $\mathrm{Y}$ ') seperti yang dilakukan oleh Lakoff dan Johnson (2003) dan Kovecses (2010). Kovecses 
(2010) memberikan sebuah ilustrasi dalam pemetaan konseptual metafora love is journey 'cinta adalah perjalanan' yang terdapat pada kalimat We aren't going anywhere 'Kita tidak akan pergi ke mana pun'. Dalam contoh tersebut, bentuk ekspresi pergi ke suatu tempat mengindikasikan bepergian ke suatu tujuan. Dalam kalimat tertentu, perjalanan dimungkinkan tidak memiliki tujuan yang pasti. Kata kita dalam hal ini mengacu pada wisawatan atau pelancong yang terlibat dalam perjalanan. Dari kalimat tersebut, terlihat tiga unsur pokok dalam perjalanan, yaitu pelancong, perjalanan, dan tujuan. Namun, ketika mendengar kalimat di atas dalam konteks yang tepat dapat ditafsirkan bahwa kalimat tersebut mengandung ungkapan tentang cinta.

Tabel 1

Korespondensi Metafora

"Cinta Adalah Perjalanan"

\begin{tabular}{l|l}
\hline \multicolumn{1}{c}{$\begin{array}{c}\text { PERJALANAN } \\
\text { (sumber) }\end{array}$} & \multicolumn{1}{c}{\begin{tabular}{c}
\multicolumn{1}{c}{ CINTA } \\
(target)
\end{tabular}} \\
\hline Pelancong & Pecinta \\
\hline Kendaraan & $\begin{array}{l}\text { Hubungan cinta itu } \\
\text { sendiri }\end{array}$ \\
\hline Perjalanan yang & $\begin{array}{l}\text { Peristiwa dalam } \\
\text { hubungan }\end{array}$ \\
\hline $\begin{array}{l}\text { Jarak yemajuan yang dibuat } \\
\text { ditempuh }\end{array}$ & Kesulitan yang dialami \\
\hline $\begin{array}{l}\text { Kendala } \\
\text { dihadapi }\end{array}$ & Tujuan hubungan \\
\hline Tujuan perjalanan
\end{tabular}

Dapat diketahui pula bahwa penutur kalimat bukanlah pelancong yang sesuangguhnya, melainkan seorang kekasih; bukan perjalanan fisik, melainkan peristiwa dalam hubungan percintaan; bukanlah tujuan fisik dari akhir perjalanan, melainkan tujuan dari hubungan percintaan. Berikut korespondensi tersebut ditampilkan dalam Tabel 1.

\section{METODE PENELITIAN}

Penelitian ini berjenis deskriptif kualitatif dalam linguistik.Data penelitian ini berwujud kalimat yang mengandung frase atau klausa berupa ungkapan metaforis tentang Pancasila. Data penelitian disediakan menggunakan metode simak dengan teknik catat (Sudaryanto, 2015). Data bersumber dari artikel pada media massa cetak nasional (Kompas dan Republika), regional (Tribun), dan lokal (Solopos) terbitan 2016-2018 dengan rincian yang dapat dilihat pada Tabel 2 .

Tabel 2

Sumber Data Metafora Pancasila

\begin{tabular}{c|c|c|c|c|c}
\hline Tahun & $\begin{array}{c}\text { Kompa } \\
\boldsymbol{s}\end{array}$ & $\begin{array}{c}\text { Repubi } \\
\text { lka }\end{array}$ & Tribun & $\begin{array}{c}\text { Solopo } \\
\boldsymbol{s}\end{array}$ & Total \\
\hline 2016 & 18 & 21 & 19 & 17 & 75 \\
\hline 2017 & 15 & 29 & 17 & 22 & 83 \\
\hline 2018 & 24 & 33 & 28 & 21 & 106 \\
\hline Total & 57 & 83 & 64 & 60 & 264 \\
\hline
\end{tabular}

Keterangan

$\mathrm{K}$ : Kompas

R: Republika

T: Tribun

S: Solopos

Setelah tersedia, data kemudian diklasifikasi berdasarkan ranah sumber dan ranah target. Kemudian, data dianalisis dengan metode padan referensial dengan teknik dasar berupa teknik pilah unsur penentu dan teknik lanjutan berupa teknik hubung banding menyamakan (Sudaryanto, 2015). Hasil analisis data disajikan dengan metode penyajian informal (Sudaryanto, 2015).

\section{PEMBAHASAN}

Konseptualisasi ungkapan metaforis tentang pancasila dapat ditunjukkan melalui pemetaan konseptualisasi yang didasarkan pada pengalaman tubuh, sifat, ciri, fungsi, dan kekuatan yang dimiliki oleh ranah sumber yang berkorespondensi dengan 
ranah target.Berikut ini deskripsi rinci konseptualisasi tersebut.

\section{Konseptualisasi Berdasarkan Fungsi}

Konseptualisasi untuk menunjukkan korespondensi antara konsep sumber dan target dapat dilakukan melalui fitur fungsi. 'Fungsi' dapat ditunjukkan melalui kegunaan dari entitas itu. Hal ini tertuang dalam data (1) berikut.

1) Pancasila harus menjadi rumah bersama bagi seluruh elemen yang telah bersepakat untuk membentuk negara satu bernama Indonesia. (Kompas, 24/2/2017)

Ungkapan rumah dalam data (1) mengindikasikan fitur fungsi, yaitu bangunan yang digunakan untuk tempat tinggal. Dengan adanya sebuah rumah, manusia-manusia dapat hidup dan tinggal di dalamnya untuk saling bekerja sama dalam membangun kehidupan. Dari ungkapan tersebut,dapat diformulasikan metafora "Pancasila Adalah Rumah". Dalam metafora ini dapat diinferensikan bahwa Pancasila dikonseptualisasikan sama dengan rumah karena fungsi yang dimiliki antara konsep Pancasila dengan konsep rumah. Rumah memiliki fungsi utama sebagai tempat tinggal insan manusia yang berbeda-beda untuk bersemayam dalam kehidupannya. Di lain pihak, Pancasila memiliki fungsi tempat bersemayamnya nilai-nilai luhur kepribadian bangsa Indonesia yang terbangun dari keberagaman yang hidup di Indonesia.

Hal serupa terdapat pula dalam data (2) berikut.

2) Menurutnya, Pancasila bisa menyatukan bangsa Indonesia karena ia merupakan semacam wadah kosong yang dapat diisi apa saja. (Republika, $7 / 11 / 2017)$

Kata wadah kosong pada data (2) memperlihatkan adanya fitur fungsi, yaitu tempat untuk menyimpan atau menaruh sesuatu. Dengan adanya wadah kosong, segala sesuatu dimungkinkan untuk bisa dimasukkan atau ditempatkan di dalamnya. Dari ungkapan tersebut, dapat diformulasikan metafora "Pancasila Adalah Wadah Kosong". Dalam metafora ini, dapat diinferensikan bahwa Pancasila dikonseptualisasikan sama dengan sebuah wadah kosong karena fungsi yang dimiliki antara konsep Pancasila dengan konsep wadah. Wadah memiliki fungsi utama sebagai tempat menaruh berbagai benda. Di lain pihak, Pancasila berfungsi untuk dapat menerima berbagai hal dari semua elemen bangsa Indonesia karena Pancasila digali dari keberagaman bangsa.

Dalam data (3), Pancasila juga dikonsepkan serupa seperti di bawah ini.

3) Arti penting Pancasila sebagai benteng yang menjaga keutuhan bangsa bisa ditanamkan sejak usia dini. (Tribun, 14/8/18)

Ungkapan benteng pada data (3) menampakkan adanya fitur fungsi, yaitu: bangunan untuk tempat berlindung atau bertahan dari serangan musuh. Dengan adanya benteng, segala sesuatu dimungkinkan untuk bisa berlindung ataupun bertahan dari apa pun, termasuk musuh. Dari ungkapan tersebut,dapat diformulasikan metafora "Pancasila Adalah Benteng". Dalam metafora ini dapat diinferensikan bahwa Pancasila dikonseptualkan sama dengan sebuah benteng karena fungsi yang dimiliki antara konsep Pancasila dengan konsep 
benteng. Benteng memiliki fungsi utama sebagai tempat berlindung dan bertahan dari musuh. Di lain pihak, Pancasila berfungsi menahan berbagai gempuran/seranganyang berasal dari berbagai arah dan berbagai bentuk yang mencoba untuk menghancurkan keutuhan bangsa Indonesia.

Pembahasan di atas menunjukkan bahwa manusia dalam menghasilkan ungkapan metaforis mengaktifkan memori semantik dengan menggunakan leksikon mental yang dimiliki untuk menciptakan kata baru atau kata yang memiliki makna melebihi makna yang telah menjadi kesepakatan. Tambahan makna didasarkan pada pengalaman yang telah tersimpan sehingga dimungkinkan kata yang memiliki makna tambahan itu disebabkan oleh letaknya yang berdampingan dengan kata lain yang menjadi pemicu kata itu memiliki makna tambahan atau karena bentuknya yang berubah.

\section{Konseptualisasi Berdasarkan Kekuatan}

Korespondensi antara konsep sumber dengan konsep target dapat ditunjukkan melalui konseptualisasi terhadap konsep sumber yang didasarkan pada fitur kekuatan yang dimiliki kedua ranah itu. Hal tersebut terdapat dalam data (4) dan (5) berikut.

4) Pancasila sudah sakti sejak kelahirannya. (Tribun, 8/4/2018)

5) Kesaktian pancasila akan hilang hanya ketika bangsa Indonesia tidak mencintainya lagi, menggantikannya secara sadar ataupun tidak dengan nilai-nilai baru.(Tribun, 8/4/2018)
Ungkapan sakti pada data (4) maupun kesaktian pada data (5) mengindikasikan suatu kekuatan yang melampaui kodrat alam. Ungkapan ini biasanya melekat pada manusia yang memiliki kekuatan yang melebihi manusia lainnya, bahkan sampai memiliki kekuatan gaib dalam diri seseorang. Konsep sakti dalam pamakaiannya berkolokasi dengan kata yang memiliki fitur [+konkret], sehingga dijumpai ungkapan Pendekar sakti itu tidak dapat dikalahkan musuhmusuhnya. Bagaimana musuh-musuhnya dikalahkan merupakan akibat dari kesaktian sang pendekar yang dapat dibuktikan secara visual. Pengalaman itu merasuk dalam manah, dan diekspresikan dalam suatu ungkapan ketika ada suatu pengalaman yang terjadi yang memiliki fitur yang serupa, yaitu bagaimana suatu entitas dapat kalah karena entitas lain yang lebih kuat. Oleh sebab itu, ungkapan metaforis itu digunakan untuk merepresentasikan pengalaman itu. Konsep ini terlihat pula dalam data (6) berikut.

6) Pancasila menghancurkan ideologi lain yang tak sepaham itu disebabkan karena Pancasila memang sakti karena ia lahir di tengah kecamuk dua kutub ideologi besar saat itu. (Tribun, 8/4/2018)

Ungkapan menghancurkan pada data (6) mengindikasikan ada suatu kekuatan untuk menjadikan sesuatu menjadi remuk. Upaya menghancurkan dilakukan dengan menggunakan kekuatannya. Konsep menghancurkan biasanya disandingkan dengan kata yang memiliki fitur [+konkret]. Dalam data itu, kata tersebut bersanding dengan kata Pancasila yang berfitur [-konkret] sehingga menampakkan bentuk metafora yang ekspresif. Pengalaman itu merasuk dalam manah dan diekpresikan dalam 
suatu ungkapan ketika ada suatu pengalaman yang terjadi yang memiliki fitur yang serupa, yaitu bagaimana suatu entitas dapat menghancurkan entitas lain karena entitas lain yang lebih kuat maka ungkapan metaforis itu digunakan untuk merepresentasikan pengalaman tersebut.

Konseptualisasi itu digunakan untuk menunjukkan korespondensi antara ungkapan lama yang konvensional menjadi ungkapan baru yang metaforis. Ini menandakan bahwa ungkapan metaforis merupakan ungkapan baru yang diciptakan secara kognitif oleh penutur. Ketika digunakan di masyarakat, ungkapan itu telah menjadi milik publik.

\section{Konseptualisasi Berdasarkan Ciri}

Konseptualisasi terhadap konsep sumber yang dijadikan dasar dalam menunjukkan korespondensi dengan konsep target dapat ditunjukkan melalui ciri yang dimiliki. Ciri yang dimaksudkan dalam tulisan ini adalah fitur semantik yang dapat menjadi penanda yang dapat dibuktikan secara visual atau dirasakan oleh indera. Data (7) berikut dijadikan dasar dalam menunjukkan konseptualisasi antara konsep target dan konsep sumber yang didasarkan pada ciri yang dimiliki oleh keduanya.

7) Elwin menambahkan bahwa Pancasila sebagai cita-cita manusia dan bangsa Indonesia cenderung sudah luntur. (Tribun, 21/8/2018)

Ungkapan luntur pada data (7) dapat dikategorikan metaforis karena dalam ungkapan itu terkandung ungkapan yang menunjukkan ciri sebagai sebuah pakaian, khususnya pada warna pakaian. Pakaian merupakan sesuatu benda yang penting bagi manusia. Pakaian ini akan terlihat bagus jika warna yang dibawanya tidak luntur. Apabila warna mulai luntur, pakaian tersebut akan tampak semakin tidak bagus untuk ditampilkan maupun dilihat sehingga cenderung seseorang akan tidak memakainya lagi.

Ungkapan luntur mengindikasikan adanya metafora "Pancasila Adalah Pakaian". Terdapat proses kognitif dalam metafora itu, yaitu konseptualisasi bahwa Pancasila dibayangkan seperti pakaian yang berciri memiliki warna tertentu yang menjadi bagian penting. Di samping itu, ada konseptualisasi bahwa apabila warna yang semakin luntur dapat menjadikan orang yang memilikinya enggan untuk memakainya. Demikianlah, dikatakan bahwa Pancasila sudah mulai tidak dikenakan oleh para pemakainya, yakni bangsa Indonesia. Konseptualisasi ini sama dengan ketika sepotong baju terlihat memiliki warna yang bagus maka pakaian itu cenderung masih akan terus dikenakan oleh pemakainya.

Strategi asosiatif seperti data (7) juga dapat dijumpai dalam data (8) berikut.

8) Apa yang terjadi jika Pancasila memudar sebagai identitas nasional? (Tribun, 5/9/2018)

Kata memudar dalam data (8) mengindikasikan adanya konseptualisasi yang menunjukkan korespondensi antara konsep Pancasila dengan sebuah gambar atau potret. Konsep gambar yang menjadi sumber memiliki fitur semantis [+coretan sketsa]. Fitur ini memicu penutur untuk menyandingkannya dengan Pancasila karena Pancasila merupakan gambaran kepribadian manusia Indonesia. Namun, fitur semantik dalam ungkapan gambar tersebut dalam kenyataan sudah mulai memudar. Masyarakat mulai telah 
banyak tidak menjaga dan tidak memedulikan gambar tersebut. Konseptualisasi seperti itu digunakan untuk menunjukkan korespondensi antara konsep Pancasila dengan konsep sebuah gambar.

\section{Konseptualisasi Berdasarkan Sifat}

Konseptualisasi yang dilakukan untuk menunjukkan korespondensi antara konsep sumber dan target dapat ditunjukkan sifat yang dimiliki konsep sumber yang berkorespondensi dengan konsep target. Sifat yang dimaksudkan di sini adalah semua fitur semantis yang menunjukkan peri keadaan yang menurut kodratnya ada pada sesuatu.Hal tersebut dapat terlihat dalam data (9) berikut.

\section{9) Pancasila harus dijaga kelanggengannya. (Republika,7/11/2017)}

Ungkapan langgeng 'kekal; abadi; tidak ada habisnya' dalam data (9) mengandung fitur semantis sifat abadi. Dari ungkapan dalam data (9), dapat diinferensikan adanya metafora "Pancasila Adalah Keabadian". Dalam metafora itu, terdapat konseptualisasi konsep sumber entitas yang bersifat kekal. Konseptualisasi itu didasarkan pada sifat yang melekat pada Pancasila sebagai satu-satunya ideologi bagi bangsa Indonesia sampai akhir zaman. Hal serupa terdapat dalam data (10) di bawah ini.

10) Panglima TNI, Gatot Nurmantyo, mengingatkan, Pancasila tidak luput juga akandigoyang. (Republika, $31 / 5 / 2017$ )

Berdasarkan data (10), dapat ditunjukkan bagaimana proses kognitif terjadi. Proses kognitif terjadi ketika penutur mendapati adanya aktivitas pihak-pihak yang mencoba mengganggu persatuan dan kesatuan bangsa Indonesia. Tindakan tersebut dilakukan dengan cara menyerang ideologi negara, Pancasila, secara bertahap atau pun halus. Tindakan itu disasarkan pada ideologi yang pada hakikatnya sudah menjadi dasar negara yang berdiri tegak dan kokoh. Konsep berdiri tegak dan kokoh tersebut dikaitkan dengan tindakan yang mencoba mengubah kedudukan tersebut. Ketika di dalam semantik memori penutur, sifat mengubah posisi tegak dan kokohnya sesuatu merupakan atribut yang dimiliki oleh suatu entitas yang dinamakan goyang, maka pikiran penutur mengarah pada penggunaan kata itu.

\section{Konseptualisasi Berdasarkan Pengalaman yang Dirasakan oleh Tubuh}

Konseptualisasi yang dilakukan penutur untuk menunjukkan korespondensi antara konsep sumber dan target dapat dilihat berdasarkan pengalaman yang dirasakan tubuh. Pengalaman tubuh dapat dirasakan oleh indera yang meliputi indera melihat, mengecap, meraba, mendengar, dan mencium. Selain itu, pengalaman tubuh juga bisa mengacu pada apa yang dirasakan oleh tubuh secara keseluruhan. Data (11) berikut menampakkan konseptualisasi ini.

11) Senator asal NTB ini juga mengatakan,Bung Karno pernah mengingatkan agar tidak meng-kecap-kan Pancasila. (Republika, 6/6/2017)

Kata meng-kecap-kan yang disandingkan dengan ungkapan Pancasila pada data 
(11) dapat dikategorikan metaforis karena ada proses konseptualisasi dalam kata kehangatan yang berkorespondensi dengan ungkapan Pancasila. Korespondensi yang ditunjukkan adalah pengalaman tubuh ketika melihat suatu masakan yang sudah jadi. Kemudian masakan jadi tersebut dicoba tambahkan kecap. Tentu, akan berbeda rasa, bahkan memungkinkan akan merusak rasa makanan. Pengalaman merasakan masakan digunakan untuk menjelaskan tindakan yang mencoba mengganggu keberadaan pancasila sebagai ideologi dengan menambah-nambahi atau memasukkan hal-hal yang tidak sesuai.

Proses kognitif data (11) dapat digambarkan bahwa ketika kata mengkecap-kan disandingkan dengan kata Pancasila yang sebelumnya si pengguna dengan memori semantiknya mencari kata yang tepat untuk dipilih sesuai dengan gambaran mental tentang usaha mengubah Pancasila maupun kata yang digunakan. Strategi asosiatif digunakan untuk mengaktifkan memori semantik dan pengalamannya serta pengalaman yang dibayangkan ketika melihat masakan yang terbuat dari racikan yang sudah tepat/pas. Pengaktifan memori semantiknya juga dilakukan berdasarkan pengalaman merasakan masakan yang dapat dikategorikan enak atau kelebihan atau kekurangan bumbu tertentu.Kedua entitas dibayangkan bagaimana komposisi Pancasila yang ada saat ini dan pengalaman ketika merasakan masakan yang mendapat porsi bumbu yang ditambah-tambahi sehingga menjadi tidak sedap untuk dipandang maupun dirasakan.

Data lain dapat dilihat pada data (12) berikut.

12) Pancasila menjadi kurang menyentuh pribadi-pribadi manusia Indonesia. (Tribun, 21/8/2018)
Kata menyentuh dalam data (12) mengandung fitur semantis 'kena sedikit; menjamah'. Kata itudisandingkan dengan kata Pancasila mengindikasikan adanya pengalaman tubuh yang merasakan ketika disentuh oleh entitas lain yang bisa melakukannya. Pengalaman merasakan atau membayangkan untuk disentuh menjadi dasar dalam mengonseptualisasikan Pancasila sebagai entitas yang bisa menyentuh. Hubungan konsep Pancasila dengan konsep menyentuh didasarkan pada pengalaman tubuh. Ketika tersentuh manusia atau entitas lain, seseorang akan dapat merasakan sesuatu di tubuhnya.

Berdasarkan data (12), dapat digambarkan bagaimana proses kognitif terjadi, yaitu ketika kata menyentuh disandingkan dengan kata Pancasila. Si pengguna memanfaatkan memori semantiknya untuk mencari kata yang tepat dengan pengalaman yang telah dimiliki ketika menyentuh. Pengalaman itu direpresentasikan oleh ungkapan yang sesuai dengan fitur-fitur semantik. Ada strategi asosiatif yang dilakukan untuk menunjukkan korespondensi ranah sumber dengan ranah target. Korespondensi yang ditunjukkan oleh kedua ranah ini adalah pengalaman yang dirasakan tubuh.

\section{PENUTUP}

Berdasarkan hasil pembahasan, dapat disimpulkan bahwa proses kognitif dalam ungkapan metaforis dipicu karena konseptualisasi yang dilakukan untuk menunjukkan korespondensi antara ranah sumber dan ranah target. Dengan kata lain, proses kognitif yang terjadi dalam menghasilkan ungkapan metaforis adalah dengan mengonseptualisasikan fungsi, kekuatan, ciri, sifat, dan pengalaman yang dirasakan oleh tubuh yang dimiliki sumber dengan yang 
dimiliki target, dengan tujuan untuk menggambarkan kejadian atau pengalaman yang dialami, dirasakan, dan dipikirkan oleh manusia yang terjadi di masyarakat. Oleh karena itu, Pancasila secara metaforis dipetakan dalam konseptualisasi "Pancasila Adalah Rumah", "Pancasila Adalah Wadah Kosong", "Pancasila Adalah Benteng", "Pancasila Adalah Pakaian", dan "Pancasila Adalah Keabadiaan".

Hasil kajian ini masih bersifat terbatas pada tataran konseptualisasi. Kemampuan kognisi manusia dalam mempersepsi sangatlah luas dan tidak terbatas jumlahnya. Untuk itu, masih terdapat celah yang bisa untuk dilakukan telaah yang lebih dalam dan komprehensif. Salah satunya adalah bagaimana strategi konseptualisasi pancasila secara menyeluruh yang belum diulas dalam tulisan ini.

\section{DAFTAR PUSTAKA}

Hartanto, W. (2018). Metafora kognitif tuturan penceramah dalam pengajian di wilayah Surakarta. Kandai, 14(2), 181-196 (DOI: 10.26499/jk.v14i2.643)

Hurford, J. R., et.al. (2007). Semantics: A coursebook. Cambridge: Cambridge University Press.

Keraf, G. (2004). Diksi dan gaya bahasa. Jakarta: PT Gramedia Pustaka Utama.

Kövecses, Z. (2005). Metaphor in culture: Universality and variation. Cambridge: Cambridge University Press.

. (2010). Metaphor: A practical introduction. Oxford: Oxford University Press.
Lakoff, G. dan Johnson, M. (2003). Metaphors we live by. Chicago dan London: The University of Chicago Press.

Nirmala, D. (2014). Conceptualized verbs in bahasa Indonesia. Prosiding KIMLI 2014. Jakarta: Masyarakat Linguistik Indonesia dan Universitas Lampung.

Parera, J.D. (2004). Teori semantik. Jakarta: Erlangga.

Pasaribu, T.A. (2013). A cognitive linguistics analysis of Indonesian love metaphors. Bahasa Indonesia dari Berbagai Perspektif. Yogyakarta: Program Studi S2 Linguistik.

Prayogi, I. (2013). Bentuk-bentuk metafora temporal bahasa Indonesia. Dalam Bahasa Indonesia dari Berbagai Perspektif. Yogyakarta: Program Studi S2 Linguistik.

Rajandran, K. (2017). From matter to spirit: Metaphors of enlightenment in Bhagavad-gita. Gema Online Journal Studies of Language. 17 (2), 163-176.

Subhan, R. F., Nur T., \& Nugraha, T.C. (2019). Konseptualisasi sifat dan perbuatan dalam metafora berunsur tubuh "tangan" pada Alquran. Kandai, 15(1), 61-74 (DOI:10.26499/jk.v15i1.1287)

Subroto, E. (2011). Pengantar studi semantik dan pragmatik. Surakarta: Cakrawala Media. 
Sudaryanto.(2015). Metode dan aneka teknik analisis bahasa. pengantar penelitian wahana kebudayaan secara linguistis. Yogyakarta: Duta Wacana University Press.

Ullman, S. (2007). Pengantar semantik. (Soemarsono, penerjemah). Yogyakarta: Pustaka Pelajar.
Wijana, I.D.P. (2015). Konseptualisasi korupsi dalam metafora bahasa Indonesia. Prosiding Seminar Nasional PIBSI XXXVII. Yogyakarta: Universitas Sanata Dharma. 